\title{
Harmonization of Arbitration Laws in some Asian and European Countries
}

\author{
A választottbíráskodásra vonatkozó jogszabályok harmonizálása \\ egyes ázsiai és európai országokban
}

\begin{abstract}
The present paper studies the relationship between domestic and international arbitration laws and the harmonization factor amongst some Asian and European jurisdictions. During the last decades, there has been a significant change and globalization in the world and with the expansion of businesses and trade a better dispute resolution mechanism is required in order to maintain the harmony in international trade. It has become a necessity to balance the domestic arbitration laws with the international ones. This brief paper identifies and comments on some of the areas where differences remain including differences in recognition and enforcement of arbitral awards in various jurisdictions over the public policy defence, and where further examination and research to reach and solve disputes amicably might be useful.
\end{abstract}

Keywords: arbitration, international commercial arbitration, public policy, harmonization

\begin{abstract}
ABSZTRAKT
A tanulmány a belföldi és a nemzetközi választottbírósági szabályozás harmonizálásával foglalkozik egyes ázsiai és európai jogrendszerek példáján keresztül. Az elmúlt évtizedekben a világgazdaságot és a világkereskedelmet érintően több jelentős változás és globalizálódás ment végbe, ami egy eddiginél hatékonyabb vitarendezési mód iránti igényt is a felszínre hozott, amely a nemzetközi kereskedelemben az egyensúly fenntartásának egyik eszköze lehet. A nemzeti jogokban létező választottbírósági szabályozásnak a nemzetközi standardokkal szükségszerüen harmonizálnia kell. A tanulmány azonositja és elemzi azokat a legfontosabb területeket a választottbírósági határozatok elismerésével és végrehajtásával kapcsolatosan, melyek a közrendi klauzulával összefüggésben gyakorlati nehézségeket okoznak.
\end{abstract}

Kulcsszavak: választottbíráskodás, nemzetközi kereskedelmi választottbíráskodás, közrendi klauzula, jogharmonizáció

With increasing globalization and international trade, many non-judicial alternatives are gaining popularity like arbitration, conciliation, negotiation, mediation, adjudication, etc. However, the procedure is not efficient enough to solve complicated issues. International commercial arbitration has gained the most popularity because of its diverse character. Arbitration is one of the procedures of dispute resolution

* Gauri Nirwal, PhD Student, Géza Marton Doctoral School of Law, University of Debrecen (Hungary); e-mail: gauri.nirwal23@gmail.com. The study was made under the scope of the Ministry of Justice's program on strengthening the quality of legal education. 
alongside commonly used procedures of conciliation and mediation. It is a way to resolve disputes outside the courts. The decision on the dispute is given by one or more people (commonly an arbitrator or arbitral tribunal) in the form of an arbitration award, which is binding on parties involved, and enforceable by their courts. More than solving political disputes, arbitration is used to resolve commercial disputes linked to mercantile law mainly or in the context of international transactions.

International contracts are an essential tool for governing contracting parties to arbitration disputes. However, there are circumstances where the public policy rules dictate that such forms of contracts are not enforceable in the jurisdiction. ${ }^{1}$ This is the result of the disparate nature of the commercial arbitration laws among countries as well as their legal procedures. Many efforts have emerged in order to harmonize international commercial arbitration. However, the basic character of the arbitration remains uncertain. There is no clear definition of arbitration laws in international or national legal systems, thus relying on the interpretation of the courts. ${ }^{2}$ In an effort to build trade relations, many national and international communities have progressed in the direction of developing a balanced worldwide regulatory structure. ${ }^{3}$ Whereas arbitration is usually seen as a focal point for many jurisdictions with different cultural and social standards ${ }^{4}$, the complexity and variation in arbitration laws brings many inconsistencies in arbitral decisions. Most recently, the United Nations has encouraged a movement for the harmonization of commercial arbitration in international treaties, regional agreements, and national laws. ${ }^{5}$ This is to ease the process of resolution and enforcement of solutions. It also adds to the efficiency and effectiveness of international arbitration practice.

The main objective of this paper is to study the integration of international commercial arbitration into national legislation, especially in certain Asian and European jurisdictions. Today efforts are being taken to harmonize the laws. This paper's working hypothesis follows the elements necessary for the harmonization of arbitration laws at international and domestic level. The prominent level of harmonization already exists among the international arbitration laws of many countries; however, many countries face a void between national and international laws. Many arbitration institutions and courts may benefit with the study of each other's regulations with an attempt to merge approaches without sacrificing any country's principles. In order to achieve my research goals, the main research methodology of this article is the doctrinal research method including legal concepts and principles (such as statutes,

\footnotetext{
${ }^{1}$ Eric A. Posner, 'Arbitration and the Harmonization of International Commercial Law: A Defense of Mitsubishi' (1999) 39 Virginia Journal of International Law 647, 647-670.

${ }^{2}$ L. Vynokurova, 'Procedure for Dispute Resolution in the International Commercial Arbitration Court' Law of (2011) 1 Ukraine: Legal Journal 91-107.

${ }^{3}$ Bernardo M. Cremades-Steven L. Plehn, 'The New Lex Mercatoria and the Harmonization of the Laws of International Commercial Transactions' (1984) 2 Boston University International Law Journal 317-348.

${ }^{4}$ Fan Kun: 'Salient Features of International Commercial Arbitration in East Asia: A Comparative Study of China and Japan' (2016) 5 American University Business Law Review 447-484.

${ }^{5}$ United Nations Secretary-General, Secretary-General's Address to International Council For Commercial Arbitration Congress, 2016. <https://www.un.org/sg/en/content/sg/statement/2016-05-09/secretary-generalsaddress-international-council-commercial> accessed 9 September 2020.
} 
cases, and rules). This research is a two-step process, since it involves locating the sources of the law first, and then interpreting and investigating the text. Additionally, the article adopts a comparative approach, where appropriate in order to examine the harmonization of arbitration laws in Asia and Europe, referring to different jurisdictions and collecting harmonization factors between the international and local laws.

\section{Integration of International Arbitration Laws into National Arbitration Laws}

With advent of globalization, and increasing trade and investment activities between countries, there has been a significant increase in international commercial transactions. ${ }^{6}$ The enactment of many international commercial codes has paved a way for worldwide harmonization of arbitration laws. The New York Convention on the Recognition and Enforcement of Foreign Arbitral Awards of 1958 has proved to be the most effective instrument in enforcing arbitration rules and regulations, with 167 Contracting States including jurisdictions like China and Russian Federation. ${ }^{7}$ Ottoarndt Glossner (1983) contended that "international arbitration cannot be responsibly conducted unless there is a certain link with the surrounding legal terrain, because it cannot exist without"8. Even though the international arbitration treaties are adopted by different jurisdictions, the international laws cannot co-exist without the national laws, leading to non-uniform arbitration practices all over the world. The enforcement of the arbitration laws is directly associated with the practice of domestic courts. Some arbitration disputes are not at all enforceable in certain countries, based on the defense of state's public policy. ${ }^{9}$ The defense of public policy is one of the most debated reasons for refusal of the enforcement of arbitral awards. Both UNCITRAL Model Law and the New York Convention provide that an award may be refused if it is contrary or in conflict to public policy in the enforcement state.

Jurisdictions which restrict the use of the public policy as a defense and give it a narrow understanding are considered as arbitration friendly, whereas jurisdictions which fail to do so are seen as arbitration unfriendly which need to change their commercial practices to be in line with the laws. ${ }^{10}$ Many times in the past, ambiguity and irregularities concerning the interpretation of public policy by domestic courts

${ }^{6}$ Kun 'Salient Features of International Commercial Arbitration in East Asia' (n 4) 447-484.

${ }^{7}$ United Nations Commission On International Trade Law, Status: Convention On The Recognition And Enforcement Of Foreign Arbitral Awards, New York, 1958. (The "New York Convention"). <https://uncitral.un.org/ en/texts/arbitration/conventions/foreign_arbitral_awards/status2> accessed 2 November 2020.

8 Ottoarndt Glossner, 'International Commercial Arbitration' (1983) 11 International Business Lawyer 9-12.

${ }_{9}$ Andrew I. Okekeifere, 'Commercial Arbitration as the Most Effective Dispute Resolution Method - Still a Fact or Now a Myth' (1998) 15 Journal of International Arbitration 81-106.

${ }^{10}$ Nihal Dsouza, 'A Case Against Taming The Public Policy Exception In The Context Of 21St Century International Arbitration' 2017 Cambridge International Law Journal. <http://cilj.co.uk/2017/02/07/a-case-againsttaming-the-public-policy-exception-in-the-context-of-21st-century-international-arbitration/> accessed 29 November 2020. 
has encouraged the losing party to rely on the defense of public policy to resist or delay its enforcement of the award. There is no integrated standard of public policy. Even though the basic idea of public policy is the same globally, the concept of public policy has been interpreted and applied differently from country to country. It all depends on the political, religious, social, cultural, and economic systems. Each State is influenced by different public problems and issues such as import laws, subsidies, regulations. Recent trends in the interpretation of the defense of public policy by lawmakers and domestic courts clearly shows that major jurisdictions are converging in the practice of adopting narrow interpretation of public policy defense. Most developed jurisdictions have similar conceptions of public policy. But then what differs is the implementation part from one country to another.

\section{Harmonization Trends in some Asian Countries}

The arbitration laws in the Asian Countries have usually adopted a conservative approach when it comes to the enforcement of arbitral awards. The domestic courts intervention in enforcement of arbitral awards has always been a controversial area. Many Asian jurisdictions are now a part of international codes and conventions, adopting their principles in order to be in line with International Arbitration standards.

India has a very old institution of arbitration laws. ${ }^{11}$ One of the major pieces of established legislation in order to govern the arbitration laws in India was the Arbitration Act of 1940. Nonetheless, the Act was only applicable to domestic arbitration proceedings. The Foreign Awards (Recognition and Enforcement) Act was enacted in the year 1961, which applied to the foreign awards. ${ }^{12}$ India also ratified the New York Convention (1958) and the Model Law (1985) which laid the background for the Arbitration and Conciliation Act of 1996 ("the Act"), of which the Preamble stated that the act was enacted with the purpose "to consolidate and amend the law relating to domestic arbitration, international commercial arbitration and enforcement of foreign arbitral awards". It was the first major step taken by the Indian legislature to harmonize the domestic and international arbitration laws in the country. The act was divided into two parts - Part I applicable on all domestic and international arbitrations where the place of the arbitration seat is in India, and Part II for enforcement of certain foreign awards under the New York Convention and Geneva Convention. ${ }^{13}$ The provisions of Part I and Part II of the Act lays down special grounds for refusal

\footnotetext{
11 The Law Commission of India in its Seventy Sixth Report on Arbitration Act of 1940 stated that Indian Arbitration practices dated back to the time of ancient smritis (legal texts) and digests. Apart from the decisions taken by the King Courts, other tribunals were recognized for dispute resolution. <https://lawcommissionofindia.nic.in/51-100/Report76.pdf> accessed 29 November 2020.

12 Section 4 of the Foreign Awards (Recognition and Enforcement) Act of 1961. It specified that a foreign award would be enforceable in India "as if it were an award made on a matter referred to arbitration in India." <http:// www.bareactslive.com/ACA/ACT551.HTM> 30 August 2020.

${ }^{13}$ Refer the Arbitration and Conciliation Act, 1996. <https://www.wipo.int/edocs/lexdocs/laws/en/in/in063en. pdf $>$ accessed 30 August 2020
} 
of the enforcement of an arbitral award including the refusal of awards if contrary to the public policy of India. ${ }^{14}$

The Indian courts have a long history of refusing arbitral awards on the grounds of public policy. However, the Indian judiciary is now on the path of aligning the application of the generally accepted notion of public policy, and so the exception must be construed narrowly. ${ }^{15}$ The developments made in the area of arbitration law was an attempt to make India an arbitration-friendly jurisdiction. In 2015, the Arbitration and Conciliation (Amendment) Act came into force after two decades of dealing with conventional attitudes of the domestic courts. Contrary to the current public policy in India, the domestic courts need serious grounds for intervention in order to refuse to enforce an award. In such circumstances, the nation assumes control of the arbitration proceedings for the sake of the protection of public order and justice; and domestic laws serve as the basis of international proceedings leading to disparities in the final enforcement judgements. The Indian Supreme Court in a judgement noted that "the legislative intent of the Arbitration Act is to harmonize domestic and international commercial arbitration with the UNCITRAL Model Law, the New York Convention and the Geneva Convention." ${ }^{16}$ In the case of Shri Lal Mahal Ltd (2013), ${ }^{17}$ the Supreme Court of India reduced the interference of courts in the enforcement of foreign arbitral awards.

Countries all across the globe are reacting towards the movement of harmonization of commercial arbitration positively. Some countries like China do not refer to the public policy on its own and provide that enforcement of a foreign award should be refused if it goes against "social and public interest". ${ }^{18}$ However, with China being an emerging economic giant, the country has also shown signs of adapting to the current trend of harmonization. ${ }^{19}$ One of the reasons behind making the domestic laws in line with the international commercial arbitration procedures is China's gigantic program of economic expansion- the One Belt One Road Initiative (OBOR). The decision through arbitration is to be enforced and interpreted by the local courts, national laws just serve as a supplement to the decision. But as China initially had no arbitration laws at the national level, it had to face many difficulties in the implemen-

\footnotetext{
${ }^{14}$ Section 34 of the Arbitration and Conciliation Act, 1996. It states that an award is not enforceable if it is contrary to the public policy applicable on domestic awards. Section 48 and 57 of the Act provides that a foreign award may refused if is contrary to the public policy of India or the law of India. <https://www.wipo.int/edocs/ lexdocs/laws/en/in/in063en.pdf> accessed 30 August 2020.

${ }^{15}$ Case of Cruz City 1 Mauritius Holdings v. Unitech Limited [2017] EX.P.132/2014 \& EA(OS) Nos. 316/2015, 1058/2015, 151/2016, 670/2016.

${ }^{16}$ Case of Chloro Controls (I) P Ltd v Severn Trent Water Purification Inc [2012] 9 SCALE 595.

17 Case of Shri Lal Mahal Ltd v Progetto Grano Spa, [2014] 2 SCC 433.The Supreme Court overruled the decisions set previously in Phulchand Export Ltd v OOO Patriot [2011] 10 SCC 300 and ONGC v Saw Pipes [2003] 5 SCC 705 which held that an arbitral award which is 'patently illegal' violates the public policy of India, widening the scope of public policy exception.

${ }^{18}$ Refer Article 260, Chapter 28 of the Law of Civil Procedure (1991). <http://cicc.court.gov.cn/html/1/219/199/ 200/644.html> accessed 24 November 2020.

19 Zhang Shouzhi, 'Arbitration Procedures And Practice In China: Overview' (2020) Thomson Reuters Practical Law <https://uk.practicallaw.thomsonreuters.com/3-520-0163?contextData=(sc. Default)> accessed 14 December 2020.
} 
tation of transitions. ${ }^{20}$ The Supreme People's Court of China in 1995 detailed that, "a lower court cannot refuse to enforce a foreign related or foreign arbitral award or deny the validity of an arbitration agreement in foreign-related or foreign arbitration proceedings without the prior examination and confirmation of the Supreme People's Court." 21 If an award is in conflict with China's sovereignty, the award will be in violation of the public policy of China. The foreign arbitral awards are enforced in China in accordance with the New York Convention, nevertheless, the enforcement is established based on the mindset of the domestic courts. ${ }^{22}$

The Supreme Court of China has introduced several judicial interpretations concerning the application of arbitration law. The role of the Supreme People's Court of China has been crucial in the development of arbitration law in the country. Not just this, a phenomenon of guiding cases has been introduced especially for the local lower courts for the ease of arbitrators when arbitrating in China. Other than this, the 2017 amendment in the Chinese Arbitration Law resulted in the establishment of China's two International Commercial Courts, which is one of the kind initiatives taken by any country. These courts created within the domestic legal setting will not only serve to resolve cross border commercial matters but also provide a comprehensive two-way dispute resolution mechanism. ${ }^{23}$

China's Supreme People's Court is relentlessly committed to reforming China's arbitration regime. The reforms related to reviewing processes, application, and enforcement of arbitral awards and related to the validation of arbitration agreement have remained the chief focus which also made Chinese arbitration practices align with international arbitration procedures. ${ }^{24}$ China's pro-arbitration attitude is not only going to be beneficial for itself and the economic (commercial) agreement it is going to have in the future but also gives a signal to the international arbitration community about Chinese evolution regarding the arbitration-friendly environment in the country, and within public policy.

\section{Harmonization Trends in Europe}

The European states have adopted a more progressive approach by adopting the European Convention on International Commercial Arbitration (1961). Apart from the adoption of the New York Convention, the United Nations has also established the

${ }^{20}$ Fan Kun, 'New Developments In Commercial Arbitration And Mediation' (2019) China Business Law Journal <https://law.asia/arbitration-mediation/> accessed 14 January 2021.

${ }^{21}$ Kun, 'Salient Features of International Commercial Arbitration in East Asia' (n 4) 447-484.

${ }^{22}$ Meng Yu, 'Judicial Review Of Arbitral Awards In China: How Courts Apply Public Policy? - China Justice Observer' (2019). <https://www.chinajusticeobserver.com/a/judicial-review-of-arbitral-awards-in-china-howcourts-apply-public-policy> accessed 12 November 2020.

23 Jingzhou Tao-Mariana Zhong, 'China's 2017 Reform of Its Arbitration-Related Court Review Mechanism with a Focus on Improving Chinese Courts' Prior-Reporting System' (2018) 35 Journal of International Arbitration 371-378.

${ }^{24}$ Anne Judith Farina, 'Talking Disputes into Harmony China Approaches International Commercial Arbitration' (1989) 4 American University Journal of International Law and Policy 137-171. 
United Nations Commission on International Trade Law (UNCITRAL) in order to further balance the controversial approach of member states while recognising and enforcing an arbitral award. Although the European Union laws bind the member states at international level with various conventions and court judgements, the member states have their own set of rules and regulations governing arbitration. Many arbitration cases have demonstrated the pro-enforcement approach of the European nations to harmonize and align the international practices with the domestic ones.

The German laws very well elucidated the application of public policy exception for refusing to enforce the international commercial arbitration awards. The interpretation of public policy adopted by the German courts is based on a narrow interpretation of its limitations of the fundamental principles of justice. ${ }^{25}$ The courts noted that the defence of public policy would be applied only when there is "gross violation of the fundamental principles of German public and economic life". ${ }^{26} \mathrm{~A}$ similar approach was followed by the French courts strongly indicating that the review on the merits of the case must not be allowed. ${ }^{27}$ The Court in the case of Thales v. Euromissile decided that the public policy might be applied only when the breach is "flagrante, effective et concrete (flagrant, effective and concrete)". ${ }^{28}$ The enforcement legislation in France and Portugal refers to "order public international" or to "the international public policy". ${ }^{29}$ The European Court of Justice in the Eco Swiss case first described the restrictive approach towards public policy exception. The ECJ stated that, "it is in the interest of efficient arbitration proceedings that review of arbitration awards should be limited in scope and that annulment of or refusal to recognise an award should be possible only in exceptional circumstances". Each country has a different understanding of "public policy", and the present shift in the approach of domestic courts in defining the public policy exception is an example of "evolving consensus" 30 and an approach towards the harmonization of international commercial arbitration. It is very crucial for the concept of international public policy to be separated from the national public policy.

The International arbitration practices in France enjoy a more laissez-faire attitude. The decisions denying the enforcement of arbitral awards is very rare and there is minimum interference of domestic courts in arbitration proceedings. Both in domestic and international arbitration, there is an evident autonomy of the arbitral

\footnotetext{
${ }^{25}$ Loukas Mistelis, 'International Law Association-London Conference (2000) Committee on International Commercial Arbitration" Keeping the Unruly Horse in Control" or Public Policy as a Bar to Enforcement of (Foreign) Arbitral Awards' (2000) 2 International Law FORUM du Droit International 248-253. (doi.org/10.1163/1 57180402772757421).

${ }^{26}$ Mark L. Movsesian, 'International Commercial Arbitration and International Courts' (2008) 18 Duke Journal of Comparative \& International Law 423-448.

${ }^{27}$ Fifi Junita, 'Public Policy Exception in International Commercial Arbitration - Promoting Uniform Model Norms' (2012) 5 Contemporary Asia Arbitration Journal 45-82.

${ }^{28}$ Case of Thales v. Euromissile, J.D.I. (2005) 357.

${ }^{29}$ Refer Articles 1498 and 1502 of Title V of the New Code of Civil Procedure (1981). <https://www.jus.uio.no/ Im/france.arbitration.code.of.civil.procedure.1981/doc.html\#158> accessed 29 November 2020.

${ }^{30}$ Shu Zhang, 'The Public Policy Exception in the Judicial Review of International Commercial Arbitral Awards an Empirical Study of Cases Reported by the Supreme People's Court of China' (2020) 24 Vindobona Journal of International Commercial Law and Arbitration 16-53.
} 
process from the judiciary. However, there have been instances when the French courts found public policy breaches when the arbitrators contravened the impartial and independence norms such as creating "inequality" between the parties ${ }^{31}$. The other public policy grounds for refusing the enforcement of an arbitral award includes arbitration of insolvency disputes ${ }^{32}$, or the original arbitration contract contradictory to public policy rules ${ }^{33}$, issues of anti-trust laws ${ }^{34}$, or fraud ${ }^{35}$. Also, in the case of Société Ouest Africaine des Bétons Industriels v State of Senegal ${ }^{36}$ the Cour de Cassation affirmed that public policy, domestic or international, is not an issue that a judge should consider when dealing with the enforcement of ICSID awards. The French Courts may only set aside an award strictly limited to the five (5) grounds, which excludes the refusal on the grounds of error of fact or law, or merits of the case. ${ }^{37}$

Belgium is a host to major multinational corporations and international organizations, which makes it a popular place with growing market and trade. ${ }^{38}$ With Brussels as a hotspot for arbitration hosting organizations like International Chamber of Commerce (ICC) Belgium and CEPANI (the Belgian Centre for Arbitration and Mediation), the arbitration trends are approaching towards more effective and harmonized dispute resolution methods. Belgium has ratified the many important international conventions on Arbitration, including the New York Convention, ICSID Convention, as well as the European convention on International Commercial Arbitration. The domestic Belgian law provides public policy defense as a valid ground for refusal of recognition and enforcement of an arbitral award. ${ }^{39}$ The Belgian public policy defense can be used in the cases of violation of competition laws, anti-suit injunctions, ${ }^{40}$ failure to respect the rights of the Defence, or violation of rules on

${ }^{31}$ Case of Soc. Excelsior Film TV v. Soc. UGC-PH, 24 March 1998.

${ }^{32}$ Case of Jean Lion et Cie S.A. v. International Company for Commercial Exchanges, XXXV Y.B. Com. Arb. 353 (2010).

33 Case of Tissot v. Neff, 29 November 1950.

${ }^{34}$ Case of Labinal v. Mors, 1993 Rev. Arb. 645.

${ }^{35}$ Philippe Fouchard-Berthold Goldman, Fouchard, Gaillard, Goldman on International Commercial Arbitration (Kluwer Law International BV 1999) 336-337.

${ }^{36}$ Case of Société Ouest Africaine des Bétons Industriels v State of Senegal, Case No. ARB/82/1.

${ }^{37}$ Article 1520 of the New French Arbitration Law (Decree No. 2011-48 of 13 January 2011) provides that an award may only be set aside where "(1) the arbitral tribunal wrongly upheld or declined jurisdiction; or (2) the arbitral tribunal was not properly constituted; or (3) the arbitral tribunal ruled without complying with the mandate conferred upon it; or (4) due process was violated; or (5) recognition or enforcement of the award is contrary to international public policy." <https://sccinstitute.com/media/37105/french_law_on_arbitration.pdf> accessed 18 December 2020.

${ }^{38}$ Belgian Foreign Trade Agency, About Belgium. <https://www.abh-ace.be/en/about_belgium> accessed 21 December 2020.

${ }^{39}$ Article 1712 (1) of the Belgian Judicial Code Chapter 6 states that "If, during arbitral proceedings, the parties settle the dispute, the arbitral tribunal shall terminate the proceedings and, if requested by the parties, shall record the settlement in an award on agreed terms, unless this violates public policy." Also, Article 1717 states that "The award may only be set aside if it is in conflict with public policy." <https://www.arbitrationbelgium. com/Arbitration\%20Rules/rules_en.pdf> accessed 20 December 2020.

${ }^{40}$ Flip Petillion, 'Arbitration Procedures And Practice In Belgium: Overview' (2019) Thomson Reuters Practical Law. <https://uk.practicallaw.thomsonreuters.com/w-013-9378?transitionType=Default\&contextData=(sc. Default)\&firstPage=true $>$ accessed 12 December 2020. 
consumer protection.$^{41}$ Recognition and enforcement of an arbitral award is clearly in conflict withpublic policy only when it is contrary to the "moral, political or economic" order of the country. However, the Belgian courts have always construed the defense of public policy with a narrow approach. Even though the European Union member states have diverse cultures and backgrounds, the general approach followed by the member states share a common framework and interpretation of the defense of public policy at the international level. ${ }^{42}$ The defense of public policy is rarely used in commercial arbitration proceedings.

\title{
4. Analysis
}

The unification of domestic laws and international laws is still subject to the judicial involvement and practice for setting aside the arbitral awards. Gu Weixia and Robert Morga $^{43}$ in their 2005 review commented that,

\begin{abstract}
"the effectiveness of international commercial arbitration, however, ultimately depends on whether the arbitral award can be enforced against the losing party, nothing frustrates business parties more than to discover, after prevailing in a hard fought and costly battle, that the result cannot be enforced."
\end{abstract}

The prospect of non-enforcement still prevails in certain jurisdictions leading to inefficiency in dispute resolution mechanisms.

There is great pressure existing on the application of public policy exceptions and various attempts are being made to follow a uniform approach in enforcement of arbitral awards. There is a great necessity for a delocalization movement across nations and unification of domestic laws and international laws. As expressed by Theodore C. Theofrastous in his referred article, "more the autonomy, more the predictability", ${ }^{44}$ the interference of the domestic courts must be minimized while recognizing and enforcing a foreign award. The similar approaches followed by the different legal systems can help in boosting the dispute mechanism system at international level, serving as the basis for international rules and regulations. ${ }^{45}$ Not only different public policies impact the decision of the courts, but the decisions are also affected by economic situation and the nature of judges. ${ }^{46}$ The unsolicited interfer-

\footnotetext{
${ }^{41}$ Françoise Lefèvre-Guillaume Croisant-Rinaldo Saporito, 'Law and Practice' (2020) International Arbitration 2020-Belgium. <https://practiceguides.chambers.com/practice-guides/international-arbitration-2020/belgium> accessed 18 December 2020.

${ }^{42}$ Federico Ferretti, EU Internal Market Law and the Law of International Commercial Arbitration: Have the EU Chickens Come Home to Roost? (Cambridge University Press 2020) 1-23. (doi:10.1017/cel.2020.1).

${ }^{43}$ Gu Weixia-Robert Morgan, 'Improving Commercial Dispute Resolution in China' (2005) 7 Asian Dispute Review 6-9.

${ }^{44}$ Theodore C. Theofrastous, 'International Commercial Arbitration in Europe: Subsidiary and Supremacy in Light of the De-Localization Debate' (1999) 31 Case Western Reserve Journal of International Law 455-494.

${ }^{45}$ Renata Brazil-David, 'Harmonization and Delocalization of International Commercial Arbitration' (2011) 28 Journal of International Arbitration 445-466.

${ }^{46}$ Kun, 'Salient Features of International Commercial Arbitration in East Asia' (n 4) 447-484.
} 
ence of the domestic courts acts as a major hindrance in enforcement of the arbitral awards.

The wider interpretation of this under Indian law has been subject to a lot of criticism. Such interpretation has led to the courts reviewing the merits of awards, as if the arbitrators were a lower tier of the court system. In order to use the defense of public policy, the enforcement of an award must invoke something more than the violation of the law of India. This pro-arbitration attitude of national courts is most apparent in the developed arbitral jurisdictions such as the USA and Europe. Arbitration is opted for due to its neutrality, speed, economy, and privacy, and not as a method to avoid mandatory laws. The concept of public policy is quite broad and open to misinterpretation. The Courts need to strict down the policies and there should be minimum intervention of courts in enforcement of arbitral awards in different jurisdictions. However, recent judicial rulings are helping India to shed its anti-arbitration image and emerge as a favourable jurisdiction for the enforcement of international arbitral awards.

Standardized local legislation and similar arbitration procedures around the world are critical to the international arbitration community's eventual harmonization. The standardization of domestic laws is likely to be aided by a representation of international arbitration law. It is important for jurisdictions to grasp the principle of public policy protection and narrow its reach rather than applying an excessively broad interpretation to it. The complexity of public policy should not be used as a reason to reject arbitral awards. There are common factors that are considered critical to growth in all jurisdictions. With restricting the reach of public policy to its core premise, further strengthening of procedural fairness grounds for setting aside or denying implementation of awards is a requirement at the moment. Despite different national laws and approaches, many jurisdictions are making an effort towards harmonization of international arbitration laws with the national courts playing a supervisory role. ${ }^{47}$ Harmonization is the only solution to the expanding diversity in the international commercial arbitration laws which do not comply with national judicial systems. It is pretty evident that similar disputes submitted for arbitration in different places will not generate similar outcomes due to the different provisions in domestic laws in the places where arbitration is taking place. The arbitral award of one case is not applicable in another hence harmonizing international laws with domestic laws and public policy becomes an indispensable reality. The current research is still in progress, with the aim of settling arbitration disputes amicably and providing additional recommendations to the international community.

\footnotetext{
${ }^{47}$ Mukesh Kumar Malviya, 'Jurisdictional Issues in International Arbitration With Special Reference To India' (2017) Bharati Law Review 36-58. <http://docs.manupatra.in/newsline/articles/Upload/03D471A1-CEC846DC-8E27-A42DC5D09E7C.pdf> accessed 20 November 2020.
} 